\title{
Using the General Equilibrium Growth Model to Study Great Depressions:
}

\section{A Rejoinder to Kehoe and Prescott}

\author{
Peter Temin
}

\begin{abstract}
The reply by Kehoe and Prescott restates their position but does not answer the criticism made in my review of their book (Temin 2008). I argued that the general equilibrium model of economic growth to study income fluctuations does not lead to a useful research program; the use of closed-economy models to understand the world problems of the 1930s and the Latin-American problems of the 1980s is not helpful; and the authors using Kehoe and Prescott's recommended approach do not use data with the care standard in other branches of economics. I stand by those criticisms.
\end{abstract}

JEL Codes E32, N10

Key words: Depressions, economic fluctuations, general equilibrium models

Department of Economics, MIT. Contact: ptemin@mit.edu. 


\section{Using the General Equilibrium Growth Model to Study Great Depressions:}

\section{A Rejoinder to Kehoe and Prescott}

Kehoe and Prescott (2008) express their unhappiness with my review (Temin, 2008) of their book (Kehoe and Prescott, 2007). I understand their unhappiness; no one likes a bad review. They score a couple of cheap shots off me ("Mexico is in North America.”). I understand that too; I could not resist scoring some cheap shots off them. They do not however confront the main argument of my review, and I take this opportunity to rescue it from the blizzard of detail in Kehoe and Prescott's reply. They chose to restate their methodology and quibble over details and definitions without confronting the main issues at stake. I attempt to redress this balance here.

I made three main points in my review. First, the general equilibrium model of economic growth to study income fluctuations does not lead to a useful research program. Second, the use of closed-economy models to understand the world problems of the 1930s and the Latin-American problems of the 1980s is not helpful. Third, the authors using Kehoe and Prescott's recommended approach do not use data in the ways that have become standard in other branches of economics. I discuss these points in turn.

The following paragraph from their reply sets up the debate:

As Cole and Ohanian stress, this sort of exercise, which takes the behavior of productivity as exogenous, does not provide us with a satisfactory theory of the U.S. Great Depression. Nonetheless, we learn a lot from the exercise because it defines very precisely what a satisfactory theory needs to do: It needs to account for the sharp fall in productivity over the period 1929-33, and it needs to explain why hours fell so sharply from 1929 to 1933 and stayed so depressed afterwards even though productivity recovered. A theory that cannot accomplish these tasks using a modified version of the model is not a successful theory in the context of the research agenda developed in Great Depressions of the Twentieth Century (Kehoe and Prescott, 2008, p. 6) 
Kehoe and Prescott argue that their model is useful because it defines a research agenda for studies of large economic downturns. They list two questions that arise from Cole and Ohanian's lead essay in their volume. The first question is why productivity fell so sharply in the Great Depression. But the observed fall in productivity typically comes at the end of the arguments in the essays in Kehoe and Prescott (2007), when it should have come at the beginning. My review reproduced statements from many essays posing but not answering the same question that Kehoe and Prescott assert is one of the aims of their approach. This suggests that the Kehoe and Prescott research strategy highlights this question but provides little guidance in answering it.

The essays collected in the book I reviewed therefore suggest this not a useful question for research. Many of those essays took Cole and Ohanian (1999) as their starting point, but none of them answered this question. Instead, they followed the example set by Cole and Ohanian and translated falls in aggregate production into falls in total factor productivity. The primary question I raised in my review is whether this translation of output falls into productivity declines resulted in a promising research strategy. The evidence from Great Depressions of the Twentieth Century is negative.

The general equilibrium model of economic growth frequently is closed by assuming perfect foresight. This may be a good assumption for the long run, but it is not as well suited to the study of large income fluctuations. One characteristic of large depressions, great or otherwise, is that they almost always are unexpected. Private investors and policy makers find out that they are in the midst of a large fluctuation as it occurs. This is very important for the analysis of policies undertaken in the course of the depression. Assuming perfect foresight rules some of the most interesting problems of 
large income fluctuations off the table. It also reduces the lessons one can draw from this kind of analysis for policy advice in the current (2008-09) economic decline.

We watched with horror as the financial system collapsed in the fourth quarter of 2008. There had been anticipatory steps toward this fall in the takeover of Fannie Mae and Freddie Mac, Bear Stearns, and even earlier failures like Enron and Long Term Capital Management. Yet perfect foresight was not in evidence. President Bush simply vanished; Treasury Secretary Paulson proposed new policies every week as he struggled to get ahead of the developing financial crisis. As I write this in spring 2009, it is too early to know if this decline is the start of another downturn that Kehoe and Prescott would classify as a great depression. But it already is abundantly clear that perfect foresight fails to illuminate the policy choices that need to be made in the short run.

The second question listed by Kehoe and Prescott is "why hours fell so sharply from 1929 to 1933 and stayed so depressed afterwards.” The obvious answer is that there was a Great Depression. Hours fell because unemployment rose and stayed high for a decade. Many economists and economic historians have asked whether the policies of the New Deal contributed to the continuing high employment. Despite sharply differing underlying models, the answers appear to be remarkably similar. Temin (1989) and Cole and Ohanian (2004) used very different models to reach similar conclusions. In fact this conclusion is no more complicated than the example of price supports in elementary economics. Kehoe and Prescott defined two tasks for a satisfactory theory in the paragraph quoted. The first task appears too hard and the second too easy for a serious research program. 
I also argued in my review that models of closed economies are not the best way to analyze large income fluctuations in the twentieth century. The various depressions and growth slowdowns in different countries were interconnected. Kehoe and Prescott do not confront this fundamental question in their reply; the reiteration of a closedeconomy model in their reply does not advance this discussion. I think that the most fruitful debate about the Great Depression and the problems in Latin America in the 1980s is about the common difficulties of so many parts of the world. The classic statement of the national view of the Great Depression can be found in Friedman and Schwartz (1963); the international view can be found in Eichengreen (1994) and Temin (1989). Here is a short version of the latter view: "To a first approximation, the spread of the Great Depression from country to country is short and straightforward: fixed exchange rates under the gold standard transmitted negative demand shocks (Temin, 1993).” I argued in my review that inattention to this debate was a defect of Great Depressions of the Twentieth Century. I am sorry that Kehoe and Prescott did not respond.

Finally, Kehoe and Prescott fault me for not finding their book's data website and making some data errors. I feel badly that I did not find the website before writing my review, but I now extend my review to say that a website is only useful if people can find it from the book. The URL is given in the book, as Kehoe and Prescott say, but it is very hard to find if you do not already know it exists. The website is not mentioned in the Table of Contents, the Forward, the Preface, and the List of Contributors. It is not mentioned in the first chapter by Kehoe and Prescott or the second chapter by Cole and Ohanian, even in their appendices and notes on data. The website was mentioned on the 
flyleaf of the book and in a few data appendices of later chapters, but it was not highlighted in the parts of the book that a reader sees when approaching the book in a normal matter.

My main point about data was not about the footnoting or numbers being used; it was about the lack of hypothesis testing. The methodology being championed by Kehoe and Prescott uses lots of theory, but it does not lead to formal tests of hypotheses. This is a turn away from the pervasive growth of hypothesis testing in the rest of economics and marks this research program as an idiosyncratic approach. There are lots of graphs in the reply by Kehoe and Prescott, but they seem only to be used to test the hypothesis that various countries had a great depression by their definition. This is not the most important hypothesis to test about large income fluctuations. I reiterate my criticism of the book and challenge Kehoe and Prescott to generate testable hypotheses that can be tested by the empirical methods at use in the rest of economics.

I made some data mistakes in my review, and a Corrigendum will appear in the Journal of Economic Literature to set the record straight (Temin, forthcoming). None of these mistakes affect the main arguments of my review; they are relevant only to the third point listed here. I am sorry that Kehoe and Prescott chose to center their reply to my review on these data mistakes instead of confronting the questions I raised in my review.

Kehoe and Prescott in their reply take issue with my assertion that there was an underlying political agenda to the studies collected in volume I reviewed. Yet in January 2009 I received an e-mail from the Cato Institute inviting me to join "Nobel laureate Ed Prescott” and sign on to the following statement.

Notwithstanding reports that all economists are now Keynesians and that we all support a big increase in the burden of government, we 
the undersigned do not believe that more government spending is a way to improve economic performance. More government spending by Hoover and Roosevelt did not pull the U.S. economy out of the Great Depression in the 1930s. More government spending also did not solve Japan's "lost decade" in the 1990s. As such, it is a triumph of hope over experience to believe that more government spending will help the United States today. To improve the economy, policy makers should focus on reforms that remove impediments to work, saving investment, and production. Lower tax rates and a reduction of the burden of government are the best ways to use fiscal policy to boost growth (Niskanin, 2009).

This looks like a political agenda to me. The policy in question is to take government out of the economy and allow the competitive market to work. The aim of this policy is to maximize GDP. No thought is given to the time it would take to get the economy growing, the distribution of income that would result, or policies to ease the pain of people caught in the economic firestorm. If economists argue like this, then it is little wonder that they are relegated far to the side in policy discussions that affect us all. This is the underlying political agenda in the book I reviewed. 


\section{References}

Cole, Harold L., and Lee E, Ohanian. 2004. “New Deal Policies and the Persistence of the Great Depression: A General Equilibrium Analysis.” Journal of Political Economy, 112: 779-816 (August).

Eichengreen, Barry, 1992. Golden Fetters: The Gold Standard and the Great Depression, 1919-1939. New York: Oxford.

Friedman, Milton, and Anna J. Schwartz, 1963. A Monetary History of the United States, 1867-1960. Princeton: Princeton University Press.

Kehoe, Timothy J., and Edward C. Prescott, 2007. Great Depressions of the Twentieth Century (eds.). Minneapolis: Federal Reserve Bank of Minneapolis.

Kehoe, Timothy J., and Edward C. Prescott, 2008. "Using the General Equilibrium Growth Model to Study Great Depressions: A Reply to Temin.” Staff Report 418, Federal Reserve Bank of Minneapolis Research Department (December).

Niskanin, Bill, 2009. E-mail (January 16).

Temin, Peter, 1989. Lessons from the Great Depression. Cambridge: MIT Press.

Temin, Peter, 1993. “Transmission of the Great Depression.” Journal of Economic Perspectives, 7: 87-102 (Spring).

Temin, Peter, 2008. "RBC Views of the Great Depression and Recent Events: A Review of Timothy J. Kehoe and Edward C Prescott's Great Depressions of the Twentieth Century,” Journal of Economic Literature, 46: 669-84 (September). 